\title{
HUBUNGAN DUKUNGAN SUAMI DENGAN KECEMASAN WANITA YANG MENGALAMI MENOPAUSE DI DUSUN KARANG JATI SLEMAN, YOGYAKARTA
}

\author{
Ika Hermawati ${ }^{1}$, Sri Arini Winarti ${ }^{2}$, Dewi Ratnasari ${ }^{3}$ \\ ${ }^{1,3}$ S1 Ilmu Keperawatan STIKes Guna Bangsa Yogyakarta, ${ }^{2}$ S1 Ilmu Keperawatan POLTEKKES \\ Kemenkes Yogyakarta
}

\begin{abstract}
Background: The husband's support was the most improved external factors in helping the wife to go through the menopause without excess anxiety.Support on women in the past through menoapuse in need of surrounding people especially the husband as life partner. Data of menopausal women a village Sleman Yogyakarta is 150 people. After a Screening at the time of the preliminary study in the hamlet of Sleman Yogyakarta there are 60 women who are anxious.
\end{abstract}

Aim: To know the relation between husband's support with anxiety woman who had menopause in Karangjati Sleman, Yogyakarta

Methods: This study used a survey of analytical research methods with cross sectional approach. The subject of this research is on 60 menopausal women. Data retrieval using guided questionnaire that have been tested by there searchers. Data analysis performed using Spearman Ranktest.

Result: The husband's support in menopausal women in the category of poor numbered 25 persons (41.7\%). The level of anxiety of menopausal women in the category of Weight numbered 39 persons $(65 \%)$. Based on the results of statistical values $P$ value $=0,014(p<0.05)$, there is a relation between husband'ssupport with anxiety woman who had menopause in KarangJati Hamlet Sleman, Yogyakarta

Conclusion:there is a relation between husband's support with anxiety woman who had menopause in Karang Jati, Sleman, Yogyakarta

Keywords:Husband's support, Anxiety, Menopause

\section{PENDAHULUAN}

Menopause adalah suatu keadaan dimana berhentinya menstruasi (amenorrhea) selama 1 tahun atau lebih pada wanita yang terjadi secara permanen (Sawitri et al., 2009). Menopause merupakan proses fisiologis tubuh yang normal saat sesorang memasuki usia lanjut. Sejalan dengan pertambahan usia, ovarium manusia menjadi tidak responsive yang kemungkinan disebabkan oleh penurunan jumlah folikel primedial yang dapat mempercepat datangnya masa menopause. Selain itu juga terjadi penurunan fungsi ovarium sehingga siklus seksual menurun (Ganong, 2005) ${ }^{1 .}$

Tanda tanda psikologis yang sering di rasakan oleh wanita menopause antara 
lain : merasa cemas, takut, mudah marah, mudah tersinggung, sulit konsentrasi, gugup, merasa tidak berguna-tidak berharga, stress dan bahkan ada yang mengalami depresi. Tanda ini akan mempengaruhi psikis wanita. Selain itu, menopause akan mempengaruhi hubungan antara suami istri. Hal ini dinyatakan oleh Kuntijoro (2002) bahwa biasanya seorang istri setelah menopause dalam kehidupan sehari-harinya cenderung menjauh dari suami. Keadaan ini menyebabkan kebutuhan biologis dan psikis suami tidak terpenuhi sehingga suami akan merasakan ketidak puasan (Dalam Fitri, 2011) ${ }^{2}$. Perubahan selama menopause akan berdampak pada kondisi psikologis sehingga di perlukan pengertian dan penerimaan dari keduanya (Lestari, 2010). Perubahan psikis yang terjadi pada masa menopause akan menimbulkan sikap yang berbeda-beda antara lain adanya suatu krisis yang dimanifestasikan dalam sintom-sintom psikologis seperti: depresi, mudah tersinggung, dan mudah menjadi marah, dan diliputi banyak kecemasan . Gejala fisik yang timbul seperti : Hot Flush (perasaan panas dari dada hingga vagina), keringat di malam hari, Dryness vagina (kekeringan pada vagina), mudah lelah (Atikah, 2010) ${ }^{3}$.

Kecemasan (ansietas/aniety) adalah gangguan alam pemanasan (affective) yang ditandai dengan perasaan ketakutan atau kekhawatiran yang mendalam dan berkelanjutan, tidak mengalami gangguan dalam menilai realitas (Reality Testing Ability/RTA, masih baik), kepribadian masih tetap utuh (tidak mengalami keretakan kepribadian/splitting of personality), perilaku dapat terganggu tetapi masih dalam batas-batas normal. (Hawari, 2001) ${ }^{4}$.

Dukungan pada wanita dalam menjalani masa menopause di butuhkan dari orang-orang sekitarnya khususnya suami sebagai pasangan hidup. Suami merupakan individu yang paling dekat dengan istri yang dapat berfungsi sebagai tempat berbagi rasa apabila istri mengalami kesulitan. Selain suami juga menyediakan dukungan yang dapat berbentuk perlindungan dan motivasi untuk penyelesaian masalah (Kasdu, 2002).

(Dalam Desi 2008) Dukungan suami merupakan faktor eksternal paling baik dalam membantu istri untuk melalui masa menopause tanpa kecemasan berlebih. Suami yang tidak menuntut istri untuk tampil dengan kesempurnaan fisik dan dapat meyakinkan baik dalam perkataan maupun tindakan, akan sangat membantu untuk meyakini bahwa tidak ada yang perlu dicemaskan ketika datang masa menopause (Lianawati, 2008) ${ }^{5}$.

Hasil wawancara yang dilakukan peneliti kepada 10 ibu menopause di Dusun Karang Jati Sleman Yogyakarta enam ibu merasakan penurunan aktivitas, kecemasan menghadapi menopause merasa kulit sudah berkerut sehingga merasa dirinya tidak cantik lagi dan hot flushes yang tiba tiba membuat mereka merasa tidak nyaman dan takut suminya tidak memperdulikan lagi karna merasa dirinya sudah keriput. Sedangkan empat orang ibu menganggap menopause tidak perlu di cemaskan lagi karna menopause sudah proses alami.

Hasil penelitian ini di harapkan memberikan manfaat antara lain :

1. Manfaat Teoritis

Hasil penelitian ini di harapkan dapat menjadi pengembangan ilmu keperawatan khususnya

2. Manfaat Praktis

a. Bagi perawat puskesmas mlati

Hasil penelitian ini di harapkan sebagai dasar pengembangan standar pelayanan kesehatan reproduksi sehingga akan meningkatkan mutu 
pelayanan asuhan keperawatan dan perawat puskesmas dapat memahami tentang bentuk dukungan suami terhadap istri usia menopause dan memberikan masukan secara tepat khususnya kepada suami istri yang menjelang menopause Di Dusun Karang Jati Seleman, Yogyakarta.

\section{b. Bagi Pendidikan Stikes Guna Bangsa}

Hasil penelitian di harapkan dapat di jadikan bahan masukan bagi mahasiswa keperawatan dalam memberikan asuhan keperawatan khususnya dalam memberikan pendidikan kesehatan reproduksi terutama menopause.

\section{METODE PENELITIAN}

Metode yang digunakan dalam penelitian ini adalah penelitian non eksperimen metode analitik kuantitatif mempunyai tata cara yaitu pengambilan keputusan, interpretasi data, dan kesimpulan berdasarkan angka-ankga yang diperoleh dari hasil analisi statistik. (Hadi, 1997, h.221). Penelitian ini untuk melihat hubungan atau pengaruh antara tingkat kecemasan ibu menghadapi menopause. Rancangan penelitian ini menggunakan cross sectional yaitu variabel-variabel yang termasuk faktor resiko dan variabel efek dilakukan pengukuran pada waktu yang bersamaan dengan cara pendekatan, observasi atau pengumpulan data, adapun waktu (Dalam Ni komamng 2012). Penelitian ini dilaksanakan pada bulan maret sampai juni 2014. Populasi adalah wilayah generalisasi berupa subjek atau objek yang di teliti untuk dipelajari dan diambil kesimpulan. Populasi penelitian ini adalah seluruh wanita menopause di Dusun Karang Jati, Sleman Yogyakarta. Jumlah wanita menopause 150 orang.Populasi target adalah ibu yang sudah menopause yang mempunyai suami. Populasi survey adalah ibu yang sudah menopause yang mempunyai suami dan warga asli dengan identitas Kartu Tanda Penduduk (KTP) di Dusun Karang Jati Sleman Yogyakarta. Setelah ibu ibu menopause di lakukan Screening di dapat 60 ibu yang cemas. Sampel penelitian adalah total populasi sebanyak 60 orang sesuai dengan. Alat ukur yang di gunakan kuesioner dengan skala pengukuran ordina. Kuesoner dukungan suami pada wanita yang mengalami menopause kuesoner berisi 27 pertanyaan tertutup dengan jawaban ya dan tidak, Kuesoner kecemasan pada wanita menopause Kuesoner berisi pertanyaan tertutup tentang kecemasan ibu menghadapi menopause yang berjumlah 20 pertanyaan dengan menggunakan skala Gutman yaitu dichotomous choice sehingga responden hanya memilih jawaban 'ya' atau 'tidak'.

Kuesioner di uji terlebih dahulu dengan uji tingkat validitas dan reliabilitasnya menggunakan software komputer dalam SPSS (Statistical Package for Social Science). Uji Validitas ini di lakukan dengan analisa butir yaitu skor yang ada pada butir di pandang sebagai nilai $x$ dan skor total di pandang sebagai nilai y. selanjutnya di hitung dengan korelasi product moment (Notoatmodjo, 2010) ${ }^{7}$.

Analisa bivariat dilakukan terhadap dua variabel yang di teliti yaitu dukangan suami pada ibu menghadapi menopause dan tingkat kecemasan ibu menghadapi menopause. Kedua variabel berupa skla ordinal, maka analisa data menggunakan ujia korelasi Spearman Rank (Hidayat, 2007). 


\section{HASIL DAN PEMBAHASAN}

1. Gambaran Umum Lokasi Penelitian

Penelitian ini di lakukan di Kabupaten Sleman Yogyakarta, Kecamatan Mlati Desa Sinduadi, Pedukuhan Karang Jati. Pada tanggal 1-6 Juni 2014. Dusun Karang Jati terbagi $8 \mathrm{Rw}$ dan $22 \mathrm{RT}$, masing masing RT memiliki 2 kader . Di Dusun Karang Jati terdapat 1 puskesmas Mlati 1. Kegitan Di Dusun Karang Jati setiap bulanya arisan warga, ibu ibu PKK, perkumpulan ibu ibu Absari dan posyandu lansia setiap tanggal 22 . Pengambilan data di laksanakan secara door to door yaitu peneliti mendatangi responden dan juga menghadiri arisan warga. Sampel yang di ambil yaitu wanita yang cemas menghadapi menopause sebanyak 60 responden.

\section{Karakteristik Responden Peneltian}

1) Karakteristik responden penelitian yang berjudul Hubungan Dukungan Suami Dengan Kecemasan Wanita Yang Mengalami Menopause Di Dusun Karang Jati Sleman

Tingkat Pendidikan wanita menopause di kelompokan menjadi 4 kelompok yaitu Sekolah Dasar (SD), Sekolah Menengah Pertama (SMP), Sekolah Menengah Atas (SMA) dan Pendidikan Tinggi (Perguruan Tinggi). Tertera Pada Tabel di bawah ini

\begin{tabular}{lll}
\hline Karakteristik & Frekuensi & $\begin{array}{l}\text { Presentase } \\
(\%)\end{array}$ \\
\hline Tingkat Pendidikan & 26 & 43,33 \\
SD & 16 & 26,67 \\
SMP & 15 & 25 \\
SMA & 3 & 5 \\
Pendidikan Tinggi & 60 & 100 \\
\hline Jumlah & 26 & 43,33 \\
\hline Status Pekerjaan & 21 & 35 \\
Bekerja & 39 & 65 \\
Tidak Bekerja & 60 & 100 \\
\hline Jumlah & 21 & 35 \\
\hline
\end{tabular}

\begin{tabular}{lll}
\hline Jumlah Anak & & \\
Tidak Memiliki Anak & 2 & 3,33 \\
Jumlah Anak $\leq 2$ & 34 & 56,67 \\
Jumlah Anak $\geq 2$ & 24 & 40 \\
\hline Jumlah & 60 & 100 \\
\hline Kelurgaserumah & & \\
Suami dan Anak & 29 & 48,33 \\
Anak & 18 & 30 \\
Suami & 13 & 21,67 \\
\hline Jumlah & 60 & 100 \\
\hline
\end{tabular}

Sumber : Analisa Data 2014

Berdasarkan hasil penelitian, tingkat pendidikan formal mayoritas adalah wanita dengan tingkat pendidikan Dasar berjumlah 26 responden $(43,33 \%)$, dan mayoritas wanita yang tidak bekerja sebanyak 39 responden $(65 \%)$ dan mayoritas wanita memiliki anak <2 sebanyak $34(56,67 \%)$ dan mayoritas responden tinggal dengan suami dan anak sebanyak 29 responden (48,33\%).

2) Karakteristik responden penelitian yang berjudul Hubungan Dukungan Suami Dengan Kecemasan Wanita Yang Mengalami Menopause Di Dusun Karang Jati Sleman

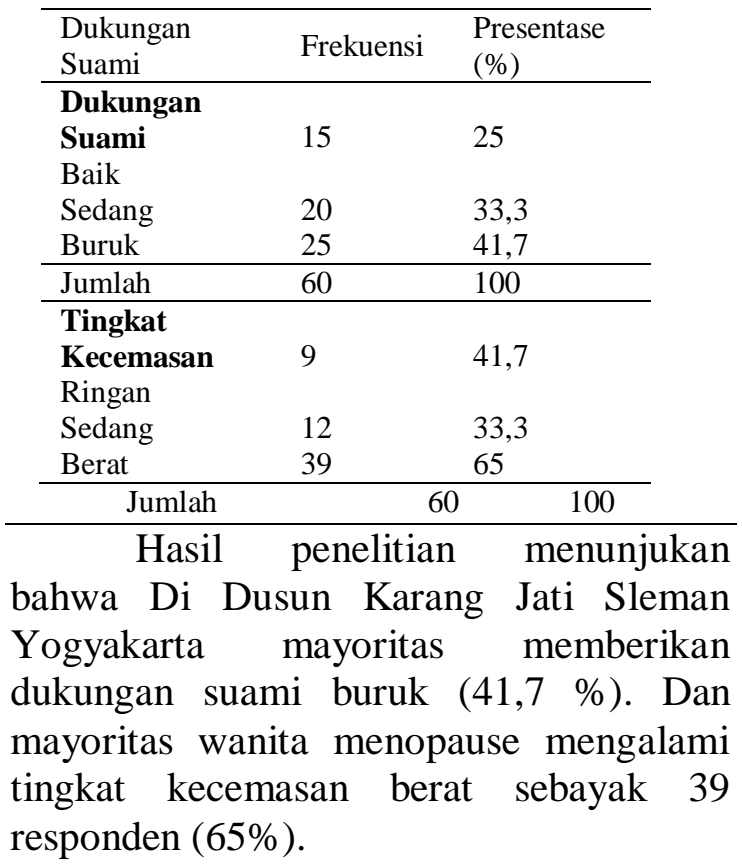




\begin{tabular}{|c|c|c|c|c|c|c|c|}
\hline \multirow{3}{*}{$\begin{array}{l}\text { Tingkat } \\
\text { Kecemas } \\
\text { an }\end{array}$} & \multicolumn{7}{|c|}{ Dukungan Suami } \\
\hline & \multicolumn{2}{|c|}{ Baik } & \multicolumn{2}{|c|}{ Sedang } & \multicolumn{2}{|c|}{ Buruk } & \multirow[t]{2}{*}{ Total } \\
\hline & $\mathrm{F}$ & $\%$ & $\mathrm{~F}$ & $\%$ & $\mathrm{~F}$ & $\%$ & \\
\hline Ringan & 6 & 10 & 2 & 3,33 & 1 & 1,66 & 9 \\
\hline ed & 5 & 8,33 & 5 & 8,33 & 2 & 3,33 & 12 \\
\hline I & 4 & 6,66 & 13 & 21,66 & 22 & 36,66 & 39 \\
\hline
\end{tabular}

\begin{tabular}{llllllll} 
Total & 15 & 24,99 & 20 & 33,32 & 25 & 41,65 & 60 \\
\hline
\end{tabular}

Berdasarkan tabel 4.7 dapat diketahui bahwa responden sebagian besar tingkat kecemasan wanita menopause ada pada kategori kecemasan berat dengan dukungan suami paling tinggi ada pada kategori buruk sebanyak 39 responden (65\%). Hasil uji statistik Spearman dengan kriteria pengujian $\mathrm{Ha}$ diterima dan $\mathrm{Ho}$ ditolak jika $p$-value $<\alpha$. Hasil analisis diperoleh nilai $p$-value sebesar 0,014. Karena $p$-value $(0,014)<\alpha(0,05)$ maka Ha diterima dan Ho ditolak, artinya hal ini menunjukkan bahwa ada hubungan antara dukungan suami dengan tingkat kecemasan pada wanita yang menghadapi menopause di Dusun Karang Jati Sleman Yogyakarta. Dengan nilai $\tau=-0,314$, artinya bahwa mempunyai keeratan hubungan antara variabel (jika tingkat kecemasan meningkat atau tinggi maka dukungan suami menurun atau rendah dan begitupun sebaliknya).

\section{KESIMPULAN DAN SARAN KESIMPULAN}

1. Dukungan suami terhadap ibu yang menghadapi menopause mayoritas memberikan dukungan $(41,7 \%)$

2 Sebanyak (65 \%) mengalami kecemasan berat.

Hasil penelitian menunjukkan bahwa Dukungan suami dengan tingkat kecemasan wanita menghadapi menopause di Dusun Karang Jati,
Sleman Yogyakarta mempunyai hubungan signifikan. Semakin baik dukungan suami maka tingkat kecemasan ibu dalam menghadapi menopause semakin rendah., dengan hasil $p$-value $0,014 \quad(p<\alpha \quad(0,05))$. Dengan tingkat keeratan negatif dengan nilai $\tau$ sebesar $-0,314$.

\section{SARAN}

a. Bagi Perawat Puskesmas Mlati

Hasil penelitian ini di harapakan sebagai dasar pengembangan standar pelayanan kesehatan reproduksi sehingga akan meningkatkan mutu pelayanan asuhan keperawatan dan perawat puskesmas dapat memahami tentang bentuk dukungan suami terhadap istri usia menopause dan memberikan masukan secara tepat khususnya kepada suami istri yang menjelang menopause Di Dusun Karang Jati Seleman, Yogyakarta.

b. Bagi Pendidikan Stikes Guna Bangsa Hasil penelitian di harapakan dapat di jadikan referensi bagi mahasiswa keperawatan untuk menambah ilmu pengetahuannya.

c. Bagi Wanita Menopause dan Suami Wanita Menopause

Bagi wanita menopause dapat lebih meningkatkan kepercayaan dirinya sehingga dapat menekan kecemasan menghadapi menopause dan bagi para suami juga di sarankan memberikan dukungan sosial yang tinggi sehingga para wanita semakin rendah tingkat kecemasannya dalam menghadapi masa menopause. misalnya dengan memberikan lebih banyak perhatian, memberikan motivasi dan memberikan informasi seputar menopause. 


\section{DAFTAR PUSTAKA}

Ferdiana. 2011. Hubungan antara dukungan sosial suami dengan mekanisme koping pada wanita menopause. Skripsi (Tidak di terbitkan). Yogyakarta : Universitas Gajah Mada.

Poverawati, Atikah. 2010. Menopause dan Sindrom Premenopause. Yogyakarta: Nuha Medika.

Hawari. 2001. Manajemen Stres Cemas dan Depresi. Jakarta : Fakultas Kedokteran Universitas Indonesia.

Deasi. 2008. Hubungan anatara dukungan sosial suami dengan kecemasan menjelang masa menopause pada ibu-ibu dharma wanita persatuan departemen agama kabupaten ponorogo jawa timur. Skripsi. Yogyakarta : Universitas Ahmad Dahlan.

Ni komang. 2012. Tingkat kecemasan ibuibu usia 40-48 tahun dalam menghadapi menopause di dusun undu kelurahan catur tunggal kecamatan depok kabupaten sleman Yogyakarta.Karya tulis ilmiah. Yogyakarta : Universitas Respati Yogyakarta.

Notoatmodjo, S. 2010. Metodologi Penelitian Kesehatan. Jakarta : Rineka dan Cipta 